\title{
Filling a gap: dynamics of space occupancy on a mussel-dominated subtropical rocky shore
}

\author{
Mutsunori Tokeshi ${ }^{1}$, Leonardo Romero ${ }^{2}$ \\ ${ }^{1}$ School of Biological Sciences, Queen Mary and Westfield College, University of London, Mile End Road, London E1 4NS, \\ United Kingdom \\ ${ }^{2}$ Laboratorio de Zoología Marina, Facultad de Ciencias Biológicas, Universidad Nacional Mayor de San Marcos, \\ Apartado 1898, Lima-100, Perú
}

\begin{abstract}
The mussel Semimytilus algosus (Gould) often dominates the space on exposed rocky shores of subtropical South America. Dynamics of space occupancy was investigated in a rocky intertidal habitat in central Peru. A series of colonization experiments and quantitative sampling of musselassociated faunas were conducted to clarify interspecific relationships among resident organisms. Spatial gaps created within the $S$. algosus zone were colonised successively by the barnacles Jehlius cirratus (Darwin) and Notochthamalus scabrosus (Darwin), a gallery-building polychaete, Phragmatopoma moerchi Kinberg, and a mussel, S. algosus. The rate of colonisation/recruitment was highest for barnacles, intermediate for $P$. moerchi and lowest for $S$. algosus. There was no evidence that barnacles either facilitate or inhibit colonisation by later colonists $P$. moerchi and $S$. algosus. Three filter-feeding taxa showed a clear competitive hierarchy. $P$. moerchi was competitively superior to barnacles and $S$. algosus was competitively superior to both barnacles and $P$. moerchi. Therefore, there are trade-offs between colonisation ability and competitive ability among these taxa. In addition to recruitment of young larvae on free rock surfaces, $S$. algosus individuals demonstrate continuous lateral migration at the edge of their aggregation, constantly expanding the boundaries. Gaps can be closed in this manner, with an average rate of edge advance of $1.2 \mathrm{~cm} \mathrm{mo}^{-1}$, which is comparable to the values estimated for Mytilus californianus on North American rocky shores. The $S$. algosus bed constitutes an important habitat to a range of organisms, many of them (particularly polychaetes) being restricted to this habitat on exposed rocky shores. Comparisons were made between faunas on free rock surfaces and in the mussel bed. Proportions of taxa restricted to the mussel bed were high among all invertebrates found there, in the range of 67 to $78 \%$ in terms of number of taxa and 80 to $94 \%$ in terms of number of individuals. Furthermore, juveniles of many organisms find refuge in the $S$. algosus bed, and barnacles which are competitively inferior to $S$. algosus can nevertheless exist epizoically on their shells. Thus, monopolisation of space by $S$, algosus generally leads to an increase in total species richness.
\end{abstract}

KEY WORDS: Gap dynamics - Space occupancy - Mussels Competition - Rocky shores - Musselassociated fauna

\section{INTRODUCTION}

How organisms use space is one of the central questions in population and community ecology. It has been recognised that many communities are characterised by a small number of dominant taxa that tend to define the physical structures of a habitat, such as forest trees, sea grass meadows and coral reefs. In the case of intertidal rocky shores, mytilid bivalves are known to dominate the space and form an extensive bed in different parts of the world (cf. Seed 1976,
Suchanek 1985, Seed \& Suchanek 1992). Apart from North American sites, however, the dynamics of space use and habitat colonisation in mussel-dominated communities have not been studied intensively. A geographically biased basis of our knowledge makes a sharp contrast to the perceived importance and generality of some ecological paradigms derived from a number of studies on species interactions in the mussel beds of North American rocky shores. Investigation on similar systems from different geographical regions is necessary for an integrative understanding 
of processes on different scales (cf. Underwood \& Denley 1984).

One of the important issues concerning the maintenance of space-monopolising structures in ecosystems relates to the aspects of recruitment and habitat colonisation. In particular, the ways in which gaps in space are formed and subsequently filled by organisms determine the nature and dynamics of community organisation. In marine benthic systems, interspecific competition as well as facilitation and inhibition are considered as important mechanisms of colonisation and succession (Connell \& Slatyer 1977). On intertidal rocky shores there is usually a range of sessile as well as mobile organisms which can colonise open space, though they do not necessarily exclude other species. Amongst these, mytilid bivalves have been described as competitive dominants capable of monopolising space which is otherwise available for colonisation by other taxa. Thus, it has widely been understood that space occupancy by mytilids could significantly reduce species diversity on a rocky shore, a situation which may in some cases be effectively hindered by starfish predation (Paine 1974). Less well understood beyond a circle of rocky shore ecologists is the fact that 3-dimensional structures created by mytilids may facilitate colonisation by certain organisms (Suchanek 1979. 1985. Tsuchiya \& Nishihira 1985, 1986, Tokeshi et al. 1989, Tsuchiya \& Bellan-Santini 1989), which would either decrease in density or altogether disappear if mytilids do not exist on the rocky substratum.

The present study deals with colonisation and space use of exposed rocky intertidal habitats in central Peru. Subtropical rocky shores on the Pacific coast of South America are often extensively colonised by 2 mussel species, Semimytilus algosus (Gould) and Perumytilus purpuratus (Lamarck) (Tokeshi et al. 1989). S. algosus appears to be restricted to low to middle latitudes of Pacific South America, while $P$. purpuratus is more common in cold temperate waters of Chile and southern Argentina. On the Pacific coast, the latter species increases in proportion towards higher latitudes and eventually forms a single mussel zone in central and southern Chile (Alveal et al. 1973, Castilla 1981). In the Peruvian intertidal where the 2 species coexist, they demonstrate distinct zonation with $S$. algosus forming a lower and often more extensive zone than an upper $P$. purpuratus zone (Paredes 1974, Tokeshi et al. 1989). The present study concentrates on the dynamics of the low/mid-intertidal S. algosus zone, which is temporally more variable and contains much higher species richness than the upper $P$. purpuratus zone. Besides $P$. purpuratus, the rock surfaces in the upper zone can be colonised only by a cirripede, Notochthamalus scabrosus (Darwin), a gastropod, Littorina peruviana (Lamarck) and a green alga, Ahnfeltia sp., due mainly to a high risk of desiccation and heat ( $M$. Tokeshi pers. obs.) (analogous to the Septifer vergatus (Wiegmann) zone above the Mytilus edulis L. zone on the Pacific northeastern Japanese coast ${ }_{i}$ cf. Hoshiai 1964, Tsuchiya 1983). S. algosus, on the other hand, sometimes extends to the subtidal where it may attain large size $(>7 \mathrm{~cm}$ ); individuals in the intertidal rarely exceed 4 $\mathrm{cm}$ in length in the study site, though they build up huge populations (density-limited growth; cf. Okamura 1986a).

The specific objectives of the present study are firstly, to clarify the patterns of colonisation on a primary rock surface in the Semimytilus algosus zone, with particular reference to the aspects of interspecific competition and facilitation/inhibition, and, secondly, to examine quantitatively the faunas associated with the mussel bed with a view to considering the possible role of $S$. algosus aggregation in either reducing or enhancing the overall species richness of a South American rocky intertidal system.

\section{MATERIALS AND METHODS}

The study was undertaken in the exposed promontory of the Ancón Bay in central Peru $\left(11^{\circ} 46^{\prime} \mathrm{S}, 77^{\circ}\right.$ $12^{\prime} \mathrm{W}$ ). A series of colonisation experiments and regular sampling of mussel-associated faunas were carried out within the Semimytilus algosus zone between April 1986 and April 1987.

Colonisation experiments. Expt A, patterns of succession: Twenty circular areas of ca $20 \mathrm{~cm}$ in diameter were cleared of organisms and within each circle a $10 \times 10 \mathrm{~cm}$ quadrat was established. At approximately fortnightly intervals colonisation was monitored using a $10 \times 10 \mathrm{~cm}$ metal frame which was subdivided into $2 \times 2 \mathrm{~cm}$ cells. On each occasion, the cumulative area of coverage by each organism was estimated by summing up coverage in individual cells; the results were expressed as the number of cells occupied. For some larger, less numerous organisms such as a gastropod Tegula atra (Lesson) individual counts were also made. In this experiment areas outside the $10 \times 10 \mathrm{~cm}$ quadrat but within the $20 \mathrm{~cm}$ circle were kept cleared of organisms to eliminate any edge effect of the Semimytilus algosus bed, i.e. the influence of individuals existing at the edge of a mussel colony either facilitating or inhibiting colonisation processes within a quadrat.

Expt B, barnacle effects: This experiment tested the effects (facilitation/inhibition) of the first colonist, barnacles, on later colonists. Quadrats were prepared as in the first experiment, and after $8 \mathrm{wk}$ to allow the establishment of barnacle colonies, 10 replicate quadrats were assigned to barnacle removal and 10 others to control. Barnacles were scraped off the rock 
substrate with a knife at the start and throughout the experimental period of 5 mo. Coverage by Phragmatopoma moerchi Kinberg and Semimytilus algosus was estimated as in Expt A.

Expt $C$, succession and competition: Following the course of events in Expts A and B, 3 separate experiments were conducted to establish the competitive relationships among colonising organisms which demonstrated successive replacement during austral spring- summer. These comprised 3 different filterfeeding taxa, the barnacles Jehlius cirratus Darwin and less commonly Notochthamalus scabrosus, a polychaete Phragmatopoma moerchi and Semimytilus algosus. In the first set of experiments, survival of barnacles was investigated. Thirty $10 \times 10 \mathrm{~cm}$ quadrat areas were cleared of organisms and left for colonisation. After $8 \mathrm{wk}$ to encourage initial settlement, these quadrats were assigned to 1 of 3 treatments (10 replicates each): (1) both $P$. moerchi and $S$. algosus removed; (2) $P$. moerchi removed, $S$. algosus left untouched; (3) both $P$. moerchi and $S$. algosus left untouched. In each treatment individuals of $S$. algosus/P. moerchi within a quadrat were carefully removed (including byssal threads and $P$. moerchi tube fragments) from the rock surface with a knife from Week 0 (start of experimental treatment) to Week 7 at weekly intervals. Abundance or spatial coverage of barnacles was assessed on Weeks 4 and 8 using the frame divided into $2 \times 2 \mathrm{~cm}$ quadrat cells. The second set of experiments dealt with the survival of $P$. moerchi with and without $S$. algosus. Twenty $10 \times 10 \mathrm{~cm}$ quadrats were established as above and 10 of these were assigned to $S$. algosus removal and the rest to control. The abundance of $P$. moerchi was assessed on Weeks 4 and 8 . The third set of experiments tested the survival of $S$. algosus with or without $P$. moerchi with 10 repli- cates each and followed the same procedures as above.

Expt D, gap filling and lateral migration: Ten circular areas of ca $35 \mathrm{~cm}$ diameter were cleared of mussels and other organisms, and lateral colonisation by the expanding edge of the Semimytilus algosus bed was monitored by measuring the gap size defined as an average of 2 measurements, i.e. the longest diameter and the longest length perpendicular to the first measurement. Monitoring was conducted at fortnightly intervals until the gaps were completely closed.

Faunal sampling. In parallel with these colonisation experiments, the fauna associated with the Semimytilus algosus bed was sampled quantitatively at bimonthly intervals. The mussel bed (ca $9 \mathrm{~m}^{2}$ in area) was mapped and grids were established to facilitate random sampling. Fifteen replicate sampling units $(10 \times 10 \mathrm{~cm}$ quadrats) were taken on each occasion. Mussels and associated organisms within a quadrat were quickly and thoroughly removed from the rock surface and transferred to a plastic bag with $10 \%$ formaldehyde. When surf intervened during the act of sampling, that sample was discarded and a new one taken; this precaution was taken in order to avoid biased sampling or loss of certain organisms such as free-ranging polychaetes. In the laboratory, samples were washed through a sieve of $0.25 \mathrm{~mm}$ mesh and individuals of different taxa were counted. Thus, the present study dealt with macrofaunal invertebrates, the majority of which reached a body size (length) of $10 \mathrm{~mm}$ or larger. Observations were also made on organisms which occurred on bare rock surfaces unassociated with the S. algosus bed. Rock surfaces within $8 \mathrm{~m}$ of shore at the study site were searched and organisms were noted for their presence. This observation covered the whole year.
Fig. 1. Variation in relative cover ( $\pm 1 \mathrm{SE}$ ) of (a) barnacles Jehlius cirratus and Notochthalamus scabrosus, (O) Phragmatopoma moerchi and (•) Semimytilus algosus

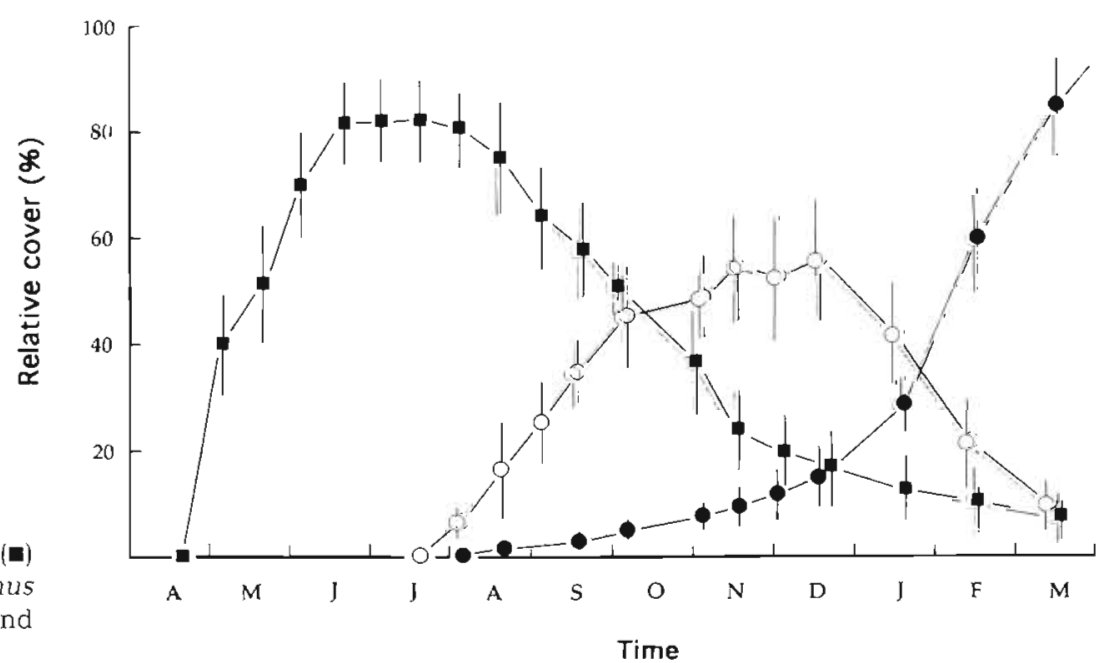




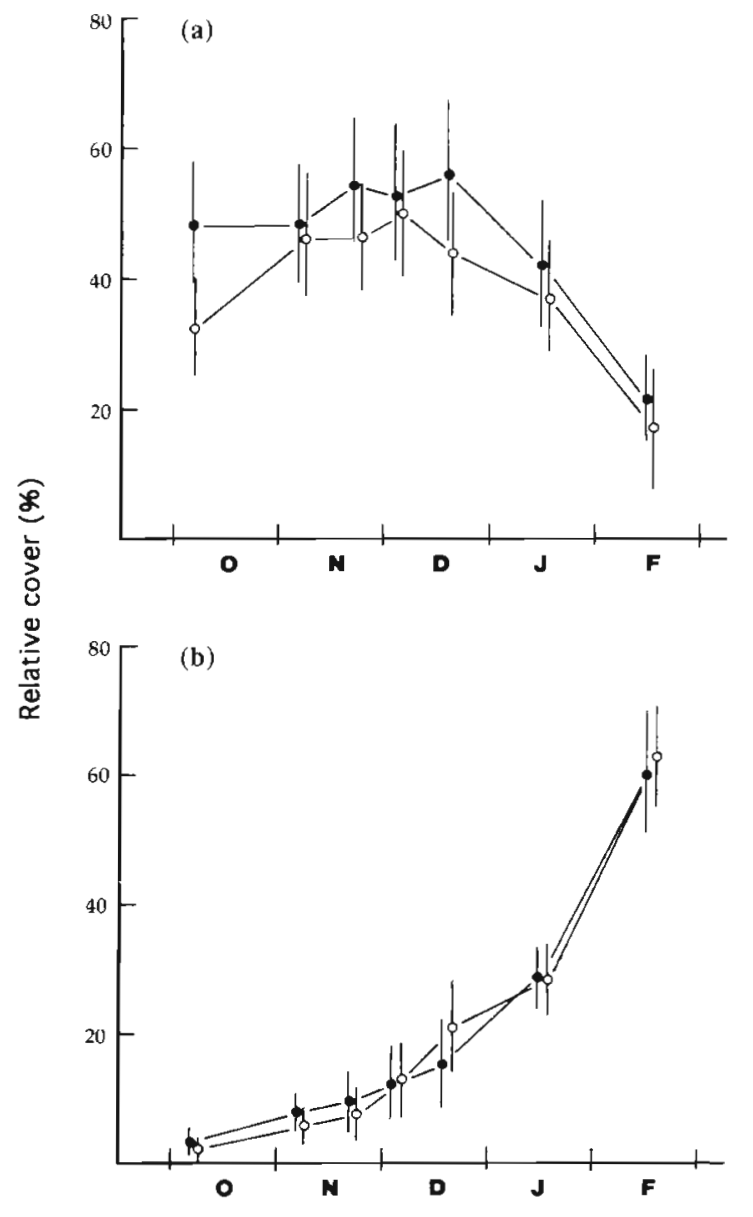

Fig. 2. Variation in relative cover ( $\pm 1 \mathrm{SE}$ ) of (a) Phragmatopoma moerchi and (b) Semimytilus algosus, in quadrats with ( ) and without (o) barnacles

\section{RESULTS}

\section{Colonisation experiments}

Expt A. Temporal patterns of colonisation on denuded rock surfaces within the Semimytilus algosus bed are shown in Fig. 1; taxa which occurred sporadically, such as Phymactis clematis (Drayton), Tegula atra and Lottia ceciliana (Orbigny), are excluded here. Barnacles, mainly Jehlius cirratus, rapidly colonised the open space and within 2 mo occupied ca $80 \%$ of cells (i.e. 20 out of 25 ). Three months after starting the experiment, a gallery-building polychaete, Phragmatopoma moerchi, started to appear and reached $60 \%$ of occupancy in $5 \mathrm{mo}$, while the abundance of barnacles steadily declined from austral winter (July-August) onwards. P. moerchi abundance in turn followed a declining trend from December onwards and, together with barnacles, virtually disappeared from the rock surface towards the end of March. $S$.
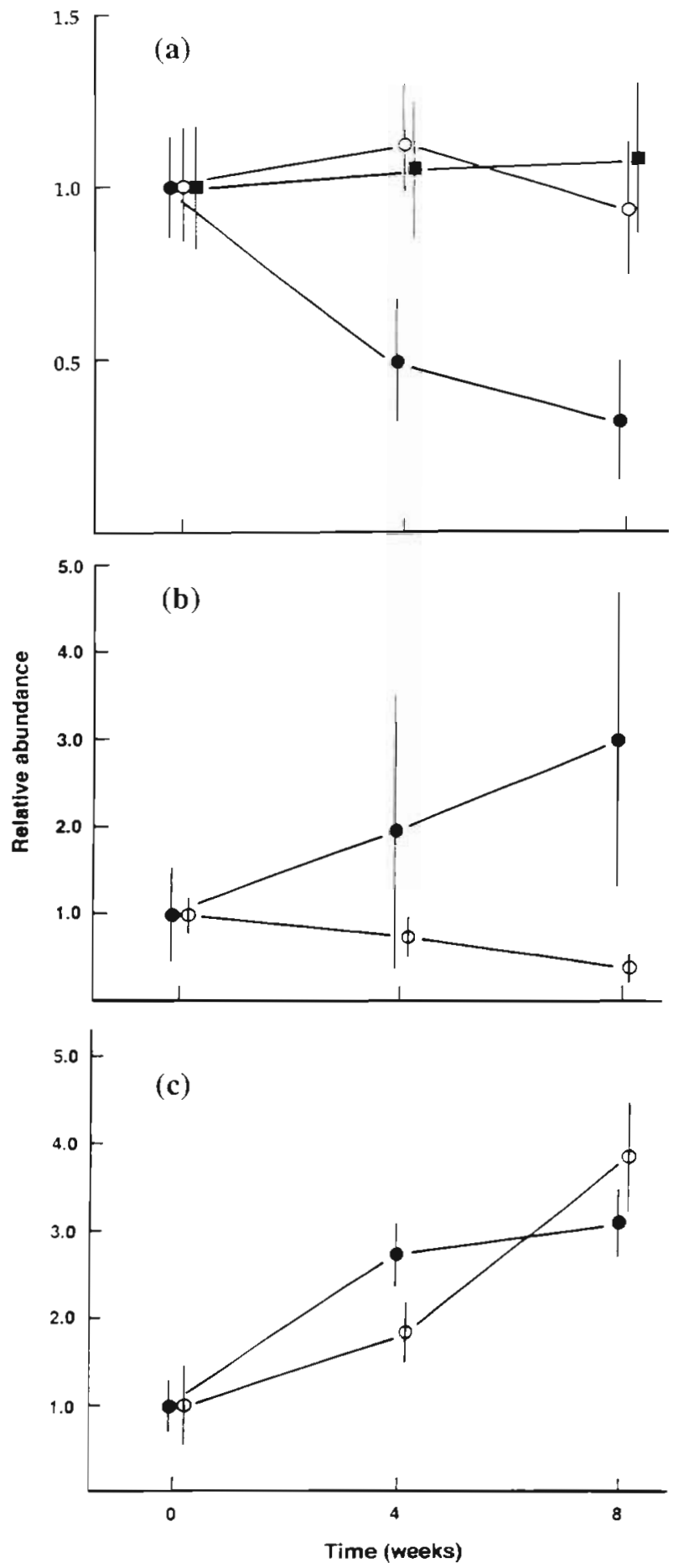

Fig. 3. (a) Relative abundances of barnacles Jehlius cirratus and Notochthalamus scabrosus in different treatments: (a) both Phragmatopoma moerchi and Semimytilus algosus removed; (O) $P$. moerchi removed, $S$. algosus untouched; (-) both P. moerchi and $S$. algosus untouched. (b) Relative abundances of $P$. moerchi when $S$. algosus was manipulated: (-) $S$ algosus removed; (O) S. algosus untouched. (c) Relative abundances of $S$, algosus when $P$. moerchi was manipulated. (-) P. moerchi removed; (O) P. moerchi untouched. All values are mean $\pm 1 \mathrm{SD}$ 
algosus first appeared in August but their increase in abundance was slow until December. Thereafter, $S$. algosus rapidly increased and virtually monopolised the space by April, although it was not completely filled until an additional 2 mo had elapsed. Thus, the 3 taxa demonstrated a clear pattern of colonisation and the open space reverted to its original state of $S$. algosus dominance within a year. It is also notable that the rate of colonisation/recruitment for the first 2 to $3 \mathrm{mo}$ of settlement was highest for barnacles $\left(2.3 \pm 0.7\right.$ cells $w^{-1}$, mean $\left.\pm 1 \mathrm{SD}\right)$, intermediate for $P$. moerchi $(1.1 \pm 0.1$ cells $\left.w^{-1}\right)$, and lowest for $S$. algosus $\left(0.19 \pm 0.07\right.$ cells wk $\left.{ }^{-1}\right)$.

Expt B. The results of the second experiment demonstrate that there is no statistically significant difference in the densities of either Phragmatopoma moerchi (Fig. 2a) or Semimytilus algosus (Fig. 2b) colonising substrates with and without barnacles. Therefore, barnacles neither facilitated nor inhibited later colonists. The effects of $P$. moerchi and $S$. algosus on one another are unlikely to alter this conclusion (see results of Expts C and D below), as each of these taxa colonised quadrats with and without barnacles in similar abundances (ANOVA for differences in density, $p>0.05$ ).

Expt $C$. The decline of the barnacles from August onwards was accompanied by increases in Phragmatopoma moerchi and Semimytilus algosus (Fig. 1), suggesting that either both or one of these species negatively affected the barnacle population. Fig. 3a shows the results of an experiment in which either $P$. moerchior $S$. algosus was removed during this period of barnacle decline. The abundances of barnacles were standardised as values relative to those on Week 0 (start of experimental treatment) in order to clarify the trends. Relative abundances of barnacles did not vary significantly when both $P$. moerchi and $S$. algosus were removed; no new recruitment of larvae seemed to have occurred during the experimental period. The same pattern of no significant variation in relative abundance was observed in the treatment where only $P$. moerchi was removed; relatively low abundance of $S$. algosus during this period seemed to have caused no significant negative effect. However, the treatment in which both $P$. moerchi and $S$. algosus were left untouched demonstrated a significant decline in barnacle abundance on Weeks 4 and 8 (ANOVA, p $<0.01$ ), as was observed in Expt A. Thus, it is reasonable to conclude that $P$. moerchi directly outcompeted barnacles during the initial phase of barnacle decline (i.e. August to December).
A decline in the Phragmatopoma moerchi population from December onwards as revealed in the first colonisation experiment was further investigated in an experiment in which Semimytilus algosus was manipulated (Fig. 3b). Relative abundances of $P$. moerchi showed contrasting trends in the 2 treatments, increasing in the absence of $S$ algosus and decreasing in its presence from Weeks 4 to 8 , though differences became statistically significant only in Week 8 (ANOVA, $\mathrm{p}<0.05$ ). Thus, $P$. moerchi was negatively affected by $S$. algosus in austral summer.

Another set of experiments tested whether the initial colonisation by Semimytilus algosus was hindered by existing individuals of Phragmatopoma moerchi. The relative abundances of $S$. algosus showed a similar pattern of increase with and without $P$. moerchi (Fig. 3c), indicating that there was no significant $(p>$ 0.05 ) negative effect of the latter species on the former.

Expt D. Open gaps were steadily colonised by Semimytilus algosus individuals at the boundaries (Fig. 4), with the mussels constantly shifting positions and expanding the periphery of their colonies. In this process barnacles and Phragmatopoma moerchi individuals which colonised the gaps were gradually overshadowed by the advancing edges of mussel aggregations. As colonisation progressed, the circular shape of the initial gap was lost due to differential rates of colonisation at different points on the boundary, leading to a rapid closing of the gap in the final phase of colonisation, i.e. January to March. The rate of colonisation or expansion of the boundary for the first 9 mo was in the range of 0.8 to $2.0 \mathrm{~cm} \mathrm{mo}^{-1}$, with an average of $1.2 \mathrm{~cm}$ $\mathrm{mo}^{-1}$. Gaps were completely closed at the end of $1 \mathrm{yr}$. 
Table 1. Invertebrate faunas observed on rock surfaces and in the Semimytilus algosus bed in the low-mid intertidal of Ancón, Peru

Taxa restricted to open rock surface (including crevices and the outer edge of a mussel bed)

Phyllactis concinnata Dana

Phymactis clematis (Drayton)

Phragmatopoma moerchi Kinberg

Austromegabalanus psittacus (Molina)

Prisogaster niger (Wood)

Fissurella spp.

Tegula atra (Lesson)

Enoplochiton niger (Barnes)

Arbacia incisa (Blainville)

Tetrapigus niger (Molina)

\section{Anthozoa}

Anthozoa

Polychaeta

Crustacea

Gastropoda

Gastropoda

Gastropoda

Polyplacophora

Echinoidea

Echinoidea
Crevice occupant Adult

Adult, large ind.

Adult

Adult

Adult

Adult

Juvenile ${ }^{a}$

Juvenile ${ }^{a}$

Juvenile ${ }^{a}$

Juvenile ${ }^{d}$

Juvenile ${ }^{ð}$
Polychaeta

Polychaeta

Polychaeta

Polychaeta

Polychaeta

Polychaeta

Polychaeta

Polychaeta

Polychaeta

Polychaeta

Ophiuroidea

Ophiactis kröyeri Lütken

Unidentified Nemertini

Unidentified isopods

${ }^{a}$ Juveniles commonly occur in mussel beds

(a)

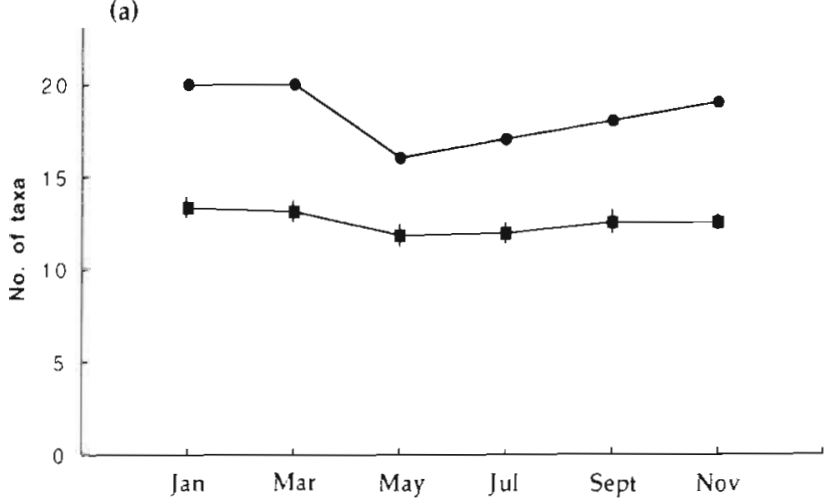

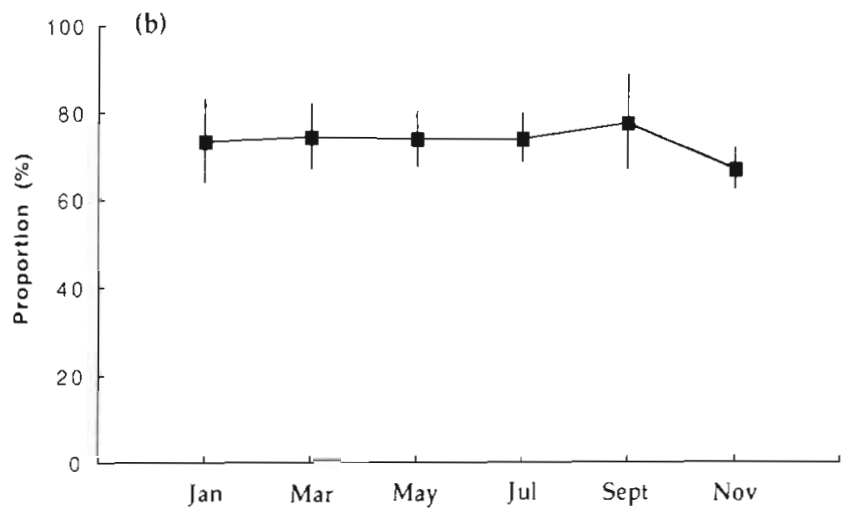

Fig. 5. (a) Total number of invertebrate taxa (15 sampling units amalgamated) associated with the Semimytilus algosus bed ( $\bullet$ ) and mean number of taxa ( \pm 1 SD) per $100 \mathrm{~cm}^{2}$ quadrat ( $)$. (b) Variation ( \pm 1 SD) in the proportion of taxa which were restricted to the mussel bed among all taxa found 
(a)

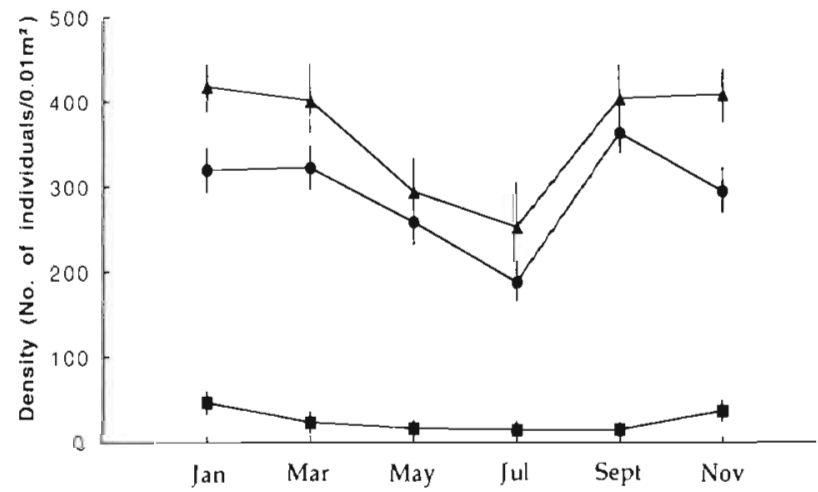

(b)

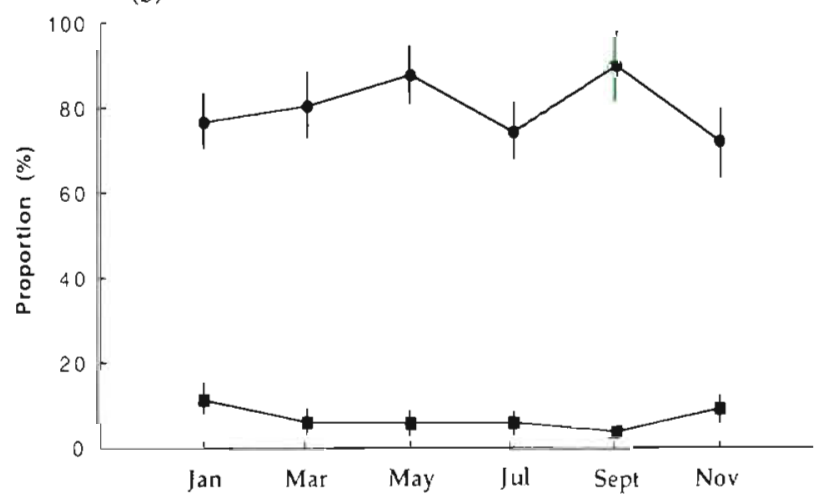

Fig. 6. Variation $( \pm 1 \mathrm{SD})$ in (a) the density of all invertebrate

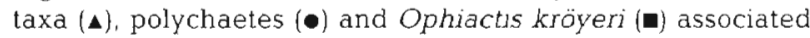
with the Semimytilus algosus bed; (b) the proportion of poly-

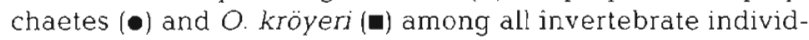
uals found in the $S$. algosus bed

\section{Mussel beds versus open space faunas}

Some taxa were restricted either to mussel beds or to open rock surfaces, while others occurred in both habitats (Table 1). These faunal compositions varied very little throughout the year. Many taxa found on open surfaces were grazers such as keyhole limpets of the genus Fissurella, gastropods (Tegula atra and Prisogaster niger) and echinoids (Tetrapigus niger and Arbacia incisa). Filter-feeding anthozoans such as Phymactis clematis and Phyllactis concinnata also occurred in the open rock substrate, the former on exposed surfaces and the latter in cracks and depressions. In contrast, the Semimytilus algosus substrate supported a wide range of predaceous and detritivorous polychaetes and ophiuroids which were not found on open rock surfaces. It is also notable that juveniles of some taxa whose adults occurred in abundance on open rocks such as $P$. clematis and $T$. atra were commonly found in the mussel bed. On the whole, it is apparent that the $S$. algosus substrate had higher spe- cies richness than open rock surfaces, due mainly to the occurrence of polychaete species which were completely missing in the latter.

The number of taxa associated with the Semimytilus algosus bed varied little throughout the year, with slightly lower numbers recorded in austral winter when the data from 15 quadrats were amalgamated (Fig. 5a). The absolute numbers of taxa are thought to be underestimated here, since the numerically most abundant group, a polychaete genus Typosyllis, is believed to contain at least 3 species which could not be distinguished in the present study. Nevertheless, the overall pattern of small variation in species richness of mussel-associated invertebrates is considered a valid observation. Amongst the mussel-associated taxa, the proportion of those restricted to this habitat was consistently high, being in a narrow range of 67 to $78 \%$ throughout the year (Fig. 5b). This was mainly due to the permanent presence of polychaete species in the S. algosus bed. In terms of density of individuals, the total density of all taxa reached a relatively low level from May to July, quickly recovering towards September (Fig. 6a). This was mainly due to fluctuations in the abundance of the most important taxa among mussel-associated invertebrates, polychaetes. The density of another taxon restricted to the $S$, algosus bed, the ophiuroid Ophiactis kröyeri, remained in the range 1470 to 4690 ind. $\mathrm{m}^{-2}$ throughout the year. Altogether, variation in the density of mussel-associated invertebrates was well within 1 order of magnitude. Finally, it is notable that the proportions of polychaetes and ophiuroids among all invertebrate individuals demonstrated little fluctuations, the former between 72 and $90 \%$ and the latter between 3.7 and $11 \%$ (Fig. 6b). Therefore, in terms of numbers of individuals, those taxa restricted to the mussel bed accounted for 80 to $94 \%$ of all invertebrates found in this habitat.

\section{DISCUSSION}

Spatial dominance by mussels has been experimentally investigated in a number of systems in North America, both intertidal (Dayton 1971, Paine 1971, 1974, Menge 1976, Peterson 1979, Paine \& Levin 1981) and subtidal (Dean \& Hurd 1980, Schoener \& Schoener 1981, Chalmer 1982, Greene \& Schoener 1982, Okamura 1986b). It has been suggested that early colonists can facilitate or inhibit the recruitment of later colonists (Connell \& Slatyer 1977, Dean \& Hurd 1980), though unequivocal quantitative data demonstrating both phenomena are sparse. In the present study there was an or derly succession by 3 filter-feeding taxa, from barnacles to the gallery-building Phragmatopoma 
moerchi and finally to Semimytilus algosus. Experimental results suggest that barnacles were competitively eliminated by $P$. moerchi and the latter was outcompeted by $S$. algosus. It is interesting to note here that amongst the 3 taxa there appear to exist trade-offs between competitive ability and colonisation ability or the initial rate of colonisation.

Mechanisms of competition were clearly identified as overgrowth of late colonists and interference with filtering. Phragmatopoma moerchi individuals constructed their galleries directly over barnacle settlements (less than $2 \mathrm{~mm}$ tall), thus physically interfering with the filtering activities of barnacles. Similarly, colonisation by Semimytilus algosus over polychaete galleries increased siltation around their entrances. This became more pronounced as mussel settlement increased. Indeed, regular sampling of the mussel bed habitat revealed a substantial amount of sand and silt being trapped under the mussels, a situation which does not exist on exposed surfaces. Overall, later colonists were clearly competitively superior to earlier colonists and there was no evidence of inhibition by the latter on the former. Thus, the barnacle- $P$. moerchi-S. algosus relationships on a Peruvian rocky shore are similar to the Chthamalus dalli-Balanus cariosusMytilus californianus relationships on a North American rocky shore (Dayton 1971). On the other hand, there was no evidence of $S$. algosus colonisation being facilitated by barnacles or polychaetes, as was the case with Mytilus spp. colonising surfaces conditioned by barnacles, hydroids or tunicates (Dayton 1971, Dean \& Hurd 1980, Okamura 1986b). It is possible that small-sized individuals of Jehlius cirratus do not alter the substrate surface textures sufficiently to enhance settlement of $S$. algosus larvae. Similarly, the presence of $P$. moerchi galleries made of sand grains do not significantly change the colonisability of a substrate by $S$. algosus. Thus, although $S$. algosus larvae were observed to settle preferentially on substrates already colonised by certain organisms, particularly algae of the genus Polysiphonia (cf. Seed 1969 in the case of $M$. edulis), neither positive nor negative interactions seem to occur with 2 filter-feeding early colonists. In a similar vein, colonisation by $P$. moerchi was neither inhibited nor facilitated by the presence of barnacles.

The above observation raises a question about the survival of barnacle and Phragmatopoma moerchi populations on the shores predominantly occupied by Semimytilus algosus. In the case of barnacles Jehlius cirratus and Notochthamalus scabrosus, both are capable of colonising the shells of $S$. algosus, thus leading an epizoic life in the $S$. algosus bed. Small adult body sizes of these species (basal size generally less than 10 $\mathrm{mm}$ ) are clearly advantageous in this respect, allowing them to find a suitable microhabitat on $S$ algosus shells. This makes a clear contrast to larger species of barnacle such as Balanus laevis (basal diameter reaching $20 \mathrm{~mm}$ ) which rarely occurred epizoically on $S$. algosus. Therefore, although $J$. cirratus and $N$. scabrosus are easily excluded from the primary rock surfaces by $S$. algosus, their populations can nevertheless persist epizoically with the mussels. It is possible that the substrate provided by $S$. algosus shells is less stable for colonising barnacles (i.e. $S$. algosus move about and may be dislodged, orientation to water currents may vary, the shell surface may peel off, etc.) than the rock surfaces, the increased surface area over the mussel bed may compensate for some loss of barnacle populations. Indeed, barnacles occur in abundance on the mussel bed throughout the year.

Phragmatopoma moerchi, on the other hand, seems incapable of leading an epizoic life on the shells of Semimytilus algosus, mainly because its tubes are relatively large (reaching $40 \mathrm{~mm}$ in length) and cannot easily be accommodated on the mussel shells. In consequence, its population tends to exist as isolated patches of colonies often established at the periphery of a mussel bed. Thus, $P$. moerchi is truly excluded by $S$. algosus aggregations and needs peripheral refugia to maintain its population.

It was observed that Semimytilus algosus has 2 different ways of filling a spatial gap: (1) colonisation by recruiting young larvae ('plantigrades') and by drifting individuals detached from substrata elsewhere; and (2) gradual lateral movement of individuals at the edge of a mussel bed. The former is a less predictable process, being dependent upon factors such as seasonality, current conditions and chance. This was demonstrated in a rather slow (initially at least) colonisation of denuded rock surfaces (Fig. 1), taking 5 mo to reach $20 \%$ cover since S. algosus first appeared. In contrast, lateral migration of individuals at the periphery of a mussel bed occurs constantly, as shown by a steady decrease in gap size (Fig. 4) throughout the year. In terms of the rate of filling a gap within a mussel bed, the latter process was much faster than free colonisation from drift. The expansion rate observed $1.2 \mathrm{~cm}$ $\mathrm{mo}^{-1}$ ) is comparable to the value obtained for Mytilus californianus on the Pacific North American coast (1.5 $\mathrm{cm} \mathrm{m}^{-1}$; Paine \& Levin 1981). Indeed, if edges were left and lateral migration were allowed in the first experiment, the $10 \times 10 \mathrm{~cm}$ quadrat would have been completely closed in less than 5 mo, probably preventing the establishment of Phragmatopoma moerchi colonies. Such a situation was observed for those gaps left after the regular sampling of $S$. algosus-associated fauna; these were very rapidly closed, generally in less than 3 mo. As this is an 'edge effect', it is natural that this mode of colonisation assumes more importance as 
gap size becomes smaller. Therefore, gaps of different sizes may be affected differently by free colonisation and lateral migration (Paine \& Levin 1981).

In addition to the dynamics of sessile organisms which occupy the primary rock surface, the present study has revealed a substantial number of taxa which were closely associated with the Semimytilus algosus bed. In parlicular, polychaetes form an important group, consistently accounting for a large proportion of the invertebrate fauna in terms of both species diversity and the number of individuals. Free-ranging predatory polychaetes require protection from predators and pounding waves in the form of an intricate matrix of mussels, which also harbour polychaetes' prey organisms. Similarly, detritivorous polychaetes as well as ophiuroids utilise detrital material accumulated in the $S$. algosus bed; apart from mussel beds, they normally occur in protected microhabitats of unexposed shores, particularly under stones. Without mussel cover, both the consumers and their resources will be lost. The bare rack surface, on the other hand, supports a range of organisms which are restricted to that habitat, particularly grazers, though the (potential) number of such taxa appears smaller than the mussel-associated fauna. In this context, whether subtropical South American rocky shores possess a relatively depauperate fauna of grazing taxa in comparison to rocky shores elsewhere is unknown. Nevertheless, it should be stressed here that juveniles of taxa in which the adult occurs on free rock substrates were often found in the $S$. algosus bed, suggesting that the latter serves as a nursery ground for many taxa.

These observations point to the importance of mussel beds as a habitat for a wide range of infaunal organisms (cf. Tsuchiya \& Nishihira 1985, 1986, Seed \& Suchanek 1992) which will inevitably disappear if the habitat is lost. This aspect of the dynamics of mussel beds has received less attention in earlier studies on the community structures of mussel-dominated rocky shores where emphasis tended to be placed on a decline in species richness as mussels monopolise space. A decline may be evident if attention is focused only on a certain range of grazing and filter-feeding taxa. The mussel beds add 3-dimensional structures to essentially 2-dimensional rock surfaces, vastly increasing the habitable space which is buffered against waves. As a result, 'spatial gaps' on the rocky shore habitat are filled not only by Semimytilus algosus but also by many other taxa. This implies that species richness is bound to decrease if mussel beds are removed by predators such as starfish [cf. the South American sun-star Heliaster helianthus (Lamarck) occurs commonly in the study site (Tokeshi 1989, 1991, Tokeshi et al. 1989, Tokeshi \& Romero 1995)] and wave actions.
Acknowledgements. This study was made possible by generous help from many individuals in the Zoology Laboratory, Universidad Nacional Mayor de San Marcos, Lima, Peru. We are grateful to Elba Canahuire, César Córdova, Carlota Estrella, Teresa Jerí, Domingo Iparraguirre, Oswaldo Cornejo, Guillermo Llerena, Drs Juan Tarazona and Carlos Paredes for the provision of facilities and solving various logistic problems in the laboratory. The study was part funded by a grant from the Agency for International Development, USA, and carried out whilst M.T was 'Profesor Invitado' at the Facultad de Ciencias Biologicas, UNMSM. Additional funding was further provided by the British Ecological Society Travelling Fellowship and the Royal Society Marine Research Grant. This paper is dedicated to the memory of Nelida 'Silvana' Tejada de Córdova, who was a promising young scientist and shared with us the joys and hardships of working in Ancon and in the Ciudad Universitaria

\section{LITERATURE CITED}

Alveal, K., Romo, H., Valenzuela, J. (1973). Consideraciónes ecológicas de las regiones de Valparaiso y de Magallanes. Rev. Biol. mar. 15: 1-29

Castilla, J. C. (1981). Perspectivas de investigación en estructura y dinámica de comunidades intermareares rocosas de Chile central. II. Depredadores de alto nivel trófico. Med. Amb. 5: 190-215

Chalmer, P. N. (1982). Settlement patterns of species in a marine fouling community and some mechanisms of succession. J. exp. mar. Biol. Ecol. 58: 73-85

Connell, J. H., Slatyer, R. O. (1977). Mechanisms of succession in natural communities and their role in community stability and organization. Am. Nat. 111. 1119-1144

Dayton, P. K. (1971). Competition, disturbance and community organization: the provision and subsequent utilization of space in a rocky intertidal community. Ecol. Monogr. 41: $351-389$

Dean, T A., Hurd, L. E. (1980). Development in an estuarine fouling community: the influence of early colonists on later arrivals. Oecologia 46: 295-301

Greene, C. H., Schoener, A. (1982). Succession on marine hard substrata: a fixed lottery. Oecologia 55: 289-297

Hoshiai, T (1964). Synecological study on intertidal communities. $V$. The interrelation between Septifer virgatus and Mytilus edulis. Bull. mar. biol. Stn, Asamushi, Tohoku Univ. 12: $37-41$

Menge, B. A. (1976). Organization of the New England rocky intertidal community: role of predation, competition, and environmental heterogeneity. Ecol. Monogr. 46: 355-393

Okamura, B. (1986a). Group living and the effects of spatial position in aggregations of Mytilus edulis. Oecologia 69 : $341-347$

Okamura, B. (1986b). Formation and disruption of aggregations of Mytilus edulis in the fouling community of San Francisco Bay, California. Mar. Ecol. Prog. Ser. 30: $275-282$

Paine, R. T. (1971). A short-term experimental investigation of resource partitioning in a New Zealand rocky intertidal habitat. Ecology 52: 1096-1106

Paine, R. T (1974). Intertidal community structure: experimental studies on the relationship between a dominant competitor and its principal predator. Oecologia 15: $93-120$

Paine, R. T., Levin, S. A. (1981). Intertidal landscapes: disturbance and the dynamics of pattern. Ecol. Monogr. 51: 145-178 
Paredes, C. (1974). El modelo de zonación en el orilla rocosa del departamento de Lima. Rev. Per. Biol. 1: 168-191

Peterson, C. H. (1979). The importance of predation and competition in organizing the intertidal epifaunal communities of Barnegat Inlet, New Jersey. Oecologia 39: 1-24

Schoener, A., Schoener, T. W. (1981). The dynamics of the species-area relationship in marine fouling systems: 1 Biological correlates of changes in the species-area slope. Am. Nat. 118: 339-360

Seed, R. (1969). The ecology of Mytilus edulis L. (Lamellibranchiata) on exposed rocky shores. I. Breeding and settlement. Oecologia 3: 277-316

Seed, R. (1976). Ecology. In: Bayne, B. L. (ed.) Marine mussels their ecology and physiology. Cambridge University Press, Cambridge, p. 13-65

Seed, R., Suchanek, T. H. (1992). Population and community ecology of Mytilus. In: Gosling, E. (ed.) The mussel Mytilus: ecology, physiology, genetics and culture. Elsevier, Amsterdam, p. 87-169

Suchanek, T. H. (1979). The Mytilus californianus community studies on the composition, structure, organization, and dynamics of a mussel bed. Ph.D thesis, University of Washington, Seattle

Suchanek, T H. (1985). Mussels and their role in structuring rocky shore communities. In: Moore, P. G., Seed, R. (eds.) The ecology of rocky coasts. Hodder \& Stoughton, Sevenoaks, p. 70-96

Tokeshi, M. (1989). Development of a foraging model for a field population of the South American sun-star, Heliaster helianthus. J. Anim. Ecol. 58: 189-206

Tokeshi, M. (1991). Extraoral and intraoral feeding: flexible foraging tactics in the South American sun-star, Heliaster

This article was submitted to the editor helianthus. J. Zool. 225: 339-347

Tokeshi, M. , Estrella, C., Paredes, C. (1989). Feeding ecology of a size-structured predator population, the South American sun-star Heliaster helianthus. Mar. Biol. 100: 495-505

Tokeshi, M., Romero, L. (1995). Quantitative analysis of foraging behaviour in a field population of the South American sun-star, Heliaster helianthus Mar. Biol. (in press)

Tokeshi, M. , Romero, L., Tarazona, J. (1989). Spatial coexistence of mussel-associated, free-ranging polychaetes in a subtropical intertidal habitat. J. Anim. Ecol. 58: 681-692

Tsuchiya, M. (1983). Mass mortality in a population of the mussel Mytilus edulis $\mathrm{L}$. caused by high temperature on rocky shores. J. exp. mar. Biol. Ecol. 66: 101-111

Tsuchiya, M., Bellan-Santini, D. (1989). Vertical distribution of shallow rocky shore organisms and community structure of mussel beds (Mytilus galloprovincialis) along the coast of Marseille, France. Mesogée 49: 91-110

Tsuchiya, M., Nishihira, M. (1985). Islands of Mytilus as habitat for small intertidal animals: effect of island size on community structure. Mar. Ecol. Prog. Ser. 25: 71-81

Tsuchiya, M., Nishihira, M. (1986). Islands of Mytilus as habitat for small intertidal animals: effect of Mytilus age structure on the species composition of the associated fauna and community organization. Mar. Ecol. Prog. Ser. 31: $171-178$

Underwood, A. J., Denley, E. J. (1984). Paradigms, explanations and generalizations in models for the structure of intertidal communities on rocky shores. In: Strong, D. R., Simberloff, D. S., Abele, L. G., Thistle, A. B. (eds.) Ecological communities: conceptual issues and the evidence Princeton University Press, Princeton, NJ, p. 151-180

Manuscript first received: July 21, 1994

Revised version accepted: December 12, 1994 